\title{
Implementation Challenges of the Public Procurement Act by Selected Metropolitan, Municipal and District Assemblies in the Ashanti Region, Ghana
}

\author{
Charles Adusei ${ }^{*}$, Dadson Awunyo-Vitor ${ }^{2}$ \\ ${ }^{1}$ Department of Accounting, Finance and Banking, Faculty of Business Studies, Garden City University College, \\ Kumasi, Ghana \\ ${ }^{2}$ Department of Agricultural Economics, Agribusiness and Extension, Faculty of Agriculture, College of \\ Agriculture and Natural Resources, Kwame Nkrumah University of Science and Technology, Kumasi, Ghana \\ Email: sircharly2002@gmail.com
}

Received 4 January 2015; accepted 12 January 2015; published 9 March 2015

Copyright (C) 2015 by authors and Scientific Research Publishing Inc.

This work is licensed under the Creative Commons Attribution International License (CC BY).

http://creativecommons.org/licenses/by/4.0/

(c) (i) Open Access

\begin{abstract}
The aim of this study is to investigate the implementation challenges of the Public Procurement Act 2003 (Act 663) by Metropolitan, Municipal and District Assemblies (MMDAs) in the Ashanti Region of Ghana. The key issues examined in the study are the level of knowledge, the procedure and modalities of compliance with the Act and the challenges of implementing the Procurement Act by the procurement committee members. Purposive sampling was adopted in selecting fourteen MMDAs while simple random procedure was used to sample members of the procurement committee at the selected MMDAs for the study. Questionnaires and focus group discussion were used to collect data and information from the respondents. Descriptive and inferential statistics were used to analyse the data. The study revealed that a large proportion of the procurement committee members could not explain key sections of the Act. In all the sampled MMDAs respondents claimed to follow procedure required by the Act. However, they enumerated the following as the key challenges with regards to the compliance of the Act: political interference, unqualified staff, and lack of monitoring as well as inadequate motivation for the committee members. There is a need for the MMDAs to take steps to address these challenges.
\end{abstract}

\section{Keywords}

Procurement, MMDAs, Ghana, Ashanti Region, Local Governance

\footnotetext{
${ }^{*}$ Corresponding author.
}

How to cite this paper: Adusei, C. and Awunyo-Vitor, D. (2015) Implementation Challenges of the Public Procurement Act by Selected Metropolitan, Municipal and District Assemblies in the Ashanti Region, Ghana. iBusiness, 7, 39-50. 


\section{Introduction}

Procurement forms an essential link among organisations in the supply chain, and it gives a mechanism for coordinating the flow of materials between customers and suppliers. At every point in the supply chain, procurement passes messages backwards to describe what customers want, and it passes messages forwards to say what suppliers have available.

Procurement is an essential function within every organization: every organization needs supply of materials, and procurement is responsible for organising this. If carried out badly, materials do not arrive, or the wrong materials are delivered, in the wrong quantities, at the wrong time, with poor quality, at too high a price, low customer service, and so on.

Procurement may be defined as the acquisition of goods, works and services. This embraces not only purchasing, that is, buying of goods, but it also includes hiring of contracts or consultants to carry out services. Standards required in procurement are: high quality service, economy and efficiency, and fairness in competition. Thus, a procedure must be followed and is applicable to all contracts for goods and works.

Public procurement has gained much attention amongst developing countries over the last decades. Developing countries have procurement budgets that account for about 20 percent of government expenditure globally [1]. Many governments have embarked on reforms in their procurement systems to streamline and harmonise legal and institutional framework.

Public procurement in Ghana represents about 24\% of total imports besides personal emoluments and public procurement amounting to $50 \%-70 \%$ of national budget and $14 \%$ of gross domestic product [2].

Studies available also indicate that consultancy works and public procurement is about US\$600 $\mathrm{m}$, [3] a figure which represents $14 \%$ of Ghana GDP. Unlike private sector procurement, public procurement is a business process within a political system, with distinct considerations of integration, accountability, national interest and effectiveness [4].

The public procurement Act of Ghana Act 663 (2003) was therefore legislated by Parliament of the Republic of Ghana to bring sanity and conformity to procurement by the institution of bodies and ethics that standardises procurement activities in the country.

Public Procurement constitutes the largest government second expenditure apart from government wage bill. It is about $50 \%$ of government expenditure. According to a World Bank report, total annual corruption in African amounts to about $\$ 148$ billion which is also about $25 \%$ of Gross Domestic Product. These corruption activities are mostly manifested in the execution of shoddy contracts and abuse of public funds which have most debilitating effects on the economy.

The bulk of government expenditure is also centered on the running of District Assemblies, Public Hospitals, Universities, schools and colleges. The smooth operations of these institutions involve the engagement of consultancy services for contract works and large procurement activities. Ensuring value for money in the operations of these institutions will inject some proficiency and subsequent budgetary savings to fund other areas of need in the government development plan. It is therefore expedient that government periodically evaluates and improves on procurement processes within the decentralised agencies and public institutions.

Governments, since independence, have formulated policies to streamline public financial management practices. Some of these financial instruments included the Contract Act of 1960, Ghana Supply Commission Act 1990 by PNDC law 245, Ghana National Procurement Agency Decree 1976 and a lot more. All these instruments were geared toward regulating procurement activities in the country.

A review of all these instruments brought to the fore gross inefficiencies such as corruption, lack of transparency in procurement activities and improper institutional and organisational framework in public procurement management. These inefficiencies brought to the fore by the review culminated into the non-achievement of value for money in public procurement.

In the quest of the government efforts to further strengthen its financial management system after a major review of public expenditure system, the government decided to establish a public financial reform programme to strengthen its financial management system. The Public Procurement Act was enacted to address perceived inefficiencies in public procurement.

[5] makes interesting findings on public procurement. It found that public procurement amounts, on average, to between $15 \%$ and $30 \%$ of GDP or and more. It also found that few activities create greater temptations or offer more avenues for corruption than public procurement. The study estimates damage from procurement-related 
corruption at normally between $10 \%$ and $25 \%$, and in some cases as high as $40 \%$ to $50 \%$ of contract value.

[6] found that the purchase of goods and services by governments in an area that warrants special attention in the fight against corruption because public procurement has a very high exposure to corruption. It estimates procurement-related corruption at about 15\% of GDP in OECD countries. It also adds that it is tempting for both public and private actors to divert goods and services or money for their personal use.

This study aimed at assessing the implementation challenges of the Public Procurement Act by selected MMDA's procurement committee members.

\section{Literature Review}

\subsection{Public Procurement Overview}

Procurement is the process by which organizations acquire goods, works and services. The procurement cycle involves planning, beginning with needs assessment through needs preparation, inviting offers, contractor selection, awarding contracts, executing and managing contracts, as well as final accounting and auditing. Procurement can therefore be viewed as a strategic component of supply chain management relating to satisfying customer or buyer needs.

According to [7] in many developing countries, public procurement has not been viewed as having a strategic impact in the management of public resources. It was largely treated as a process-oriented, function often implemented by non-professional staff of the buying agencies. Consequently, little effort was made to ensure that the policies and rules and the institutional framework governing the procurement system were maintained in a manner that ensured that public funds were used in the most efficient and economical way to deliver the best value for money.

[8] indicated that, the rules guiding government purchasing and contracting need to be accountable and transparent. This does not only limit corruption but contributes to a more accountable relationship between government and citizens. It is also important because of the huge sums involved. Furthermore, government procurement accounts forms approximately $4.5 \%$ of developing countries' "gross domestic product" (GDP) and governments tend to be the largest single consumer of goods and services in most countries. A government's use of purchasing can thus be a very significant tool to achieve socio-economic objectives. If procurement reform is done accountably, with a view to achieving both cost effectiveness and broader development goals, it can play a powerful role in poverty reduction [8].

Public procurement has been identified as the government activity most vulnerable to corruption. As a major interface between the public and the private sectors, public procurement provides multiple opportunities for both public and private sectors to divert public funds for private gain. For example, according to the 2005 Executive Opinion Survey of the World Economic Forum, bribery by international firms in Organization for Economic Cooperation and Development (OECD) countries is more pervasive in public procurement than in utilities, taxation, judiciary and state capture [6]. Furthermore, [9] stipulated that developing countries are characterised by relatively low levels of competition and have limited or no formal competition policy. Even though government procurement accounts for a significant share of public spending, the procedures for awarding and monitoring contracts lack transparency. [10] also argued that it is important for developing countries to establish formal competition policies, primarily because of structural changes due to privatisation and deregulation. The main objectives of the public procurement reforms are value for money, efficiency, transparency, probity and accountability [11].

\subsection{Public Procurement Reform in Ghana}

Ghana has made several attempts to address the weaknesses in its public procurement system by the passage of several financial and legal instruments. These attempts were in the form of constitutional, legislative instruments, administrative instructions and financial circulars. The Government, in 1960, enacted the Ghana Supply Commission Act which was reviewed later in 1990 by PNDC law 245. In the same year, Contracts Act, Act 25 of 1960 was also passed. In 1976, the National Procurement Agency Decree SMCD 55 was passed by the Supreme Military Council. In 1979, another law, the Financial Administration Decree SMCD 221 was also passed. All these laws, decrees and instruments were meant to provide a comprehensive framework of administrative powers to regulate the activities of procurement within the public sector [12]. 
However, Ghana Supply Commission and National Procurement Agency which were established were involved directly in frontline procurement and therefore did not perform the oversight responsibility to oversee the successful implementation of these laws. Since there was no legal body to perform the oversight responsibility, the procurement system was characterised by unclear legal framework, lack of harmonised procedures and regulations and unclear institutional and organisational arrangement required in the management of the public procurement. Furthermore, there was the absence of clearly defined roles and responsibilities of individual procurement entities; and no independent appeals process with power to address complaint from aggrieved bidders and provide corrective solutions. Also, there was the absence of authority to dispose off public assets and no independent audit function to ensure efficient accountability.

It became evident therefore that, there was the need to critically examine the processes and procedures of public sector procurement to ensure operational efficiency and institutional capacity to address the various shortcomings.

In Ghana, public procurement is one of the most controversial issues because it has both economic, social and governance implications. Ghana decided to fundamentally reform its procurement system to ensure efficient, fair and transparent public procurement. It was intended to promote the use of public procurement as a tool for national development. Ghana's effort to reform its procurement system is part of the Government's effort to operationalise its concept of good governance. According to [13], the public procurement reform programme is part of a wider reform agenda targeted at improving public financial management.

A key deliverable of the procurement reform was a draft Public Procurement Bill, which was enacted into law by Parliament of Ghana in 2003. Direct measures also undertaken by Government include: the issuance and monitoring of expenditure ceilings for each Ministry, Department and Agency (MDA) consistent with the annual budget and updated cash flow forecasts; and implementing new anti-corruption strategies including codes of conduct for state officials. All procuring entities must seek clearance from the Ministry of Finance, through certification as proof of the availability and adequacy of funding, before any works contract is awarded [13]. [8] stated that procurement reform is a standard good governance reform, and is generally accompanied by reform to the civil service; legal, judicial and security sectors; revenue and budget systems; and electoral, financial and administrative decentralisation.

In 1996, the Government of Ghana launched the Public Financial Management Reform Programme (PUFMARP) with the aim to improve overall public financial management in Ghana. In 1999, the Government of Ghana established the Public Procurement Oversight Group to steer the development of a comprehensive public procurement reform programme. The Public Procurement Bill was drafted in 2002 and this was passed into law on 31st of December 2003 as the Public Procurement Act (PPA) of 2003, Act 663. The PPA Act 663 requires that various government institutions set up procurement departments within their organizations which will be directly responsible for all their own procurement activities.

\section{Study Area and Methodology}

\subsection{Study Area}

The study area is Ashanti Region which is located in southern Ghana and third largest of 10 administrative regions, occupying a total land surface of $24,389 \mathrm{~km}^{2}$ (9417 sq. mi) or 10.2 percent of the total land area of Ghana. In terms of population, however, it is the most populated region with a population of 4,780,380 in 2010 , accounting for 19.4 percent of Ghana's total population. The Ashanti region and Asanteman is known for its major gold bar and cocoa production and also harbors the capital city of Kumasi.

The Ashanti region is in Asanteman and centrally located in the middle belt of Ghana. It lies between longitudes $0.15^{\circ} \mathrm{W}$ and $2.25^{\circ} \mathrm{W}$, and latitudes $5.50^{\circ} \mathrm{N}$ and $7.46^{\circ} \mathrm{N}$. The region shares boundaries with four of the ten political regions, Brong-Ahafo Region in the north, Eastern region in the east, Central region in the south and Western region in the South west. The region is divided into 27 districts, each headed by a district chief executive.

\subsection{Methodology}

Two stage sampling procedure was used to sample the respondents. At the first stage, purposive sampling pro- 
cedure was used to sample one (1) metropolitan, four (4) municipals and nine (9) districts for the study. The selection of the MMDAs was informed by the level of procurement activities undertaken by this district and how active their procurement committee members are. Second stage of the sampling process involved simple random sampling of procurement committee members. In all nine respondents were sampled from each assembly resulting in a total number of one hundred and twenty-six (126) sampled respondents in (Table 1). Questionnaire and focus group discussion were used to collect data and information from the respondents. One hundred and five questionnaires were returned given about eighty-three (83) percent response rate.

Descriptive statistics was used to analyse the data with the aid of Statistical Package for the Services Solution (SPSS). Descriptive statistics such as frequency tables and percentages were used to present the socio-economic characteristics of respondents and their levels of compliance with the Procurement Act.

\section{Results and Discussion}

\subsection{Demographic Characteristics of the Respondents}

The respondents were grouped into three different age categories. Table 2 represents the age distribution of the respondents. The age group 30 to 39 years represents $(28 \% ; n=29)$ of the respondents, 40 to 49 years represent $(27 \% ; n=28)$ and 50 to 59 years representing $(45 \% ; n=28)$ of the respondents recorded a very high percentage. This information implies that MMDAs have mature procurement committee members. The maturity in terms of ages of the respondents was normal as there is the need for mature persons to serve on any of the committees at the assemblies.

The female representation of the respondents was $(26 \%$; $n=27)$ as compared to $(74 \% ; n=78)$ for males as depicted in Table 2. The skewed result in favour of male may be attributed to the nature and composition of most of the District Assemblies committees. This information depicts that the dominance of men over women at committees' level is still very strong. It should be noted that it was encouraging to see women representation on the procurement committee.

Education is a crucial variable because it helps in the understanding and application of basic concepts, principles and regulations in the Act. It was important to find out the level of education of the respondents as this will help to assess the level of which they can appreciate key issues in the Act. All the respondents have some

Table 1. Distribution of Assemblies, number of respondents sampled and number of questionnaires returned per assembly.

\begin{tabular}{cccc}
\hline & Name & Number of respondents & Number of questionnaires returned \\
\hline 1 & Adansi North-DA & 9 & $\mathbf{8}$ \\
2 & Ahafo Ano North-DA & 9 & $\mathbf{7}$ \\
3 & Ahafo Ano South-DA & 9 & $\mathbf{8}$ \\
4 & Amansie Central-DA & 9 & $\mathbf{7}$ \\
5 & Asante Akim South-DA & 9 & $\mathbf{7}$ \\
6 & Asokore Mampong-MA & 9 & $\mathbf{8}$ \\
7 & Atwima Kwanwoma-DA & 9 & $\mathbf{9}$ \\
8 & Bekwai-MA & 9 & $\mathbf{7}$ \\
9 & Ejisu-Juaben-MA & 9 & $\mathbf{9}$ \\
10 & Ejura Sekyedumase-MA & 9 & $\mathbf{6}$ \\
11 & Kumasi Metropolitan & 9 & $\mathbf{7}$ \\
12 & Kwabre East-DA & 9 & $\mathbf{7}$ \\
13 & Offinso-MA & 9 & $\mathbf{8}$ \\
14 & Kumawu-DA & 9 & $\mathbf{7}$ \\
& Total & 126 & $\mathbf{1 0 5}$
\end{tabular}

Source: Field Data, 2014 DA—District Assembly; MA—Municipal Assembly; The response rate is about 83\%. 
Table 2. Summary of sample.

\begin{tabular}{|c|c|c|c|}
\hline Variable & Category & Frequency & Percentage \\
\hline \multirow{2}{*}{ Gender } & Male & 78 & 74 \\
\hline & Female & 27 & 26 \\
\hline \multirow{4}{*}{ Age } & Total & 105 & 100 \\
\hline & 30 - 39 years & 29 & 28 \\
\hline & 40 - 49 years & 28 & 27 \\
\hline & 50 - 59 years & 48 & 45 \\
\hline \multirow{4}{*}{ Educational Level } & Total & 105 & 100 \\
\hline & Bachelor's Degree & 24 & 23 \\
\hline & Master's Degree & 81 & 77 \\
\hline & Total & 105 & 100 \\
\hline \multirow{7}{*}{ Position of Respondent } & District Chief Executive & 16 & 15 \\
\hline & District Coordinating Director & 13 & 12 \\
\hline & Head of Supply & 15 & 14 \\
\hline & District Engineer & 16 & 15 \\
\hline & District Planning Officer & 9 & 9 \\
\hline & Director, Health Services & 12 & 11 \\
\hline & Deputy Director—HR & 24 & 24 \\
\hline \multirow{6}{*}{ Years of Service } & Total & 105 & 100 \\
\hline & $6-10$ years & 61 & 58 \\
\hline & $11-15$ years & 12 & 11 \\
\hline & 16 - 19 years & 2 & 2 \\
\hline & Above 20 years & 30 & 29 \\
\hline & Total & 105 & 100 \\
\hline
\end{tabular}

Source: Field data, 2014.

appreciable level of formal education. This is quite impressive of the management team and committee membership of the District Assemblies. In all $(23 \% ; n=24)$ respondents have Bachelor's Degree and $(77 \% ; n=81)$ with Master's degree in various disciplines (see Table 2).

As presented in Table 2, out of the one hundred and five (105) respondents who took part in the study, (58\%; $\mathrm{n}=61)$ had spent between 6 to 10 years at work, whereas $(11 \% ; n=12)$ had spent between 11 to 15 years. For the duration of 20 years and above, $(29 \% ; n=30)$ of the respondents were found. Having spent 20 years or more working with district assemblies in various capacities they are likely to better comply with the Act due to their experience with local governance issues. The number of years that respondents have spent in their work place can determine their experience which will influence their level of understanding as well as the extent to which they can comply with the Public Procurement Act [14]. This finding also confirms [15] assertion that officers who have spent 20 years or more working with the Act tend to acquire enough experience that help them to effectively comply with the Act.

It is evident from Table 3 that the level of knowledge regarding the Act was very high. In all the statement about the Act which was presented to the respondents expressed views which showed that they have some level of knowledge about the Public Procurement Act (Act 663). The Act stipulates that all public sector institutions are required to fully apply the Act to their procurement system. The respondents knowledge about this statement in the Act was collaborated by $(85.7 \%$; $=90)$ who strongly agreed to the fact that the Act is applicable to the MMDAs, as compared to $(9.3 \% ; \mathrm{n}=10)$ who disagreed. 
Table 3. Level of knowledge regarding the Act.

\begin{tabular}{|c|c|c|c|}
\hline Statements & Agree & Neutral & Disagree \\
\hline The Act is applicable to the District Assembly & $90(85.7 \%)$ & $5(5 \%)$ & $10(9.3 \%)$ \\
\hline All contracts are awarded by the tender committee & $89(84.7 \%)$ & $3(3 \%)$ & $13(12.3 \%)$ \\
\hline All contracts must pass through the procurement process & $95(90.5 \%)$ & $0(0 \%)$ & $10(9.5 \%)$ \\
\hline Procurement process is supervised by a tender committee & $86(82 \%)$ & $3(3 \%)$ & $16(15 \%)$ \\
\hline Goods and services required for emergency purposes do not go through tender & $57(54 \%)$ & $0(0 \%)$ & $48(46 \%)$ \\
\hline A procurement plan must be prepared and approved & $105(100 \%)$ & $0(0 \%)$ & $0(0 \%)$ \\
\hline A tender evaluation committee check all tenders & $79(75 \%)$ & $6(6 \%)$ & $20(19 \%)$ \\
\hline The assembly tender committee needs five members to form a quorum & $91(86 \%)$ & $7(7 \%)$ & $7(7 \%)$ \\
\hline There are training programmes on the Act & $83(79 \%)$ & $4(4 \%)$ & $18(17 \%)$ \\
\hline Are you familiar with the Public Procurement Act, Act 663 on reforms on Ghana & $97(92 \%)$ & $5(5 \%)$ & $3(3 \%)$ \\
\hline
\end{tabular}

Source: Field Data, 2014.

In addition, $(84.7 \% ; \mathrm{n}=89)$ respondents agreed that under the PPA, all contracts are awarded by a tender committee as compared to $(12.3 \% ; \mathrm{n}=13)$ who disagreed with the statement relating to this issue and $(3 \% ; \mathrm{n}=$ 3) were indifferent on the statement. Overall, more than half of the respondents agreed that the tender committee award all contracts for the supply of goods and services for MMDAs as outlined in the Act (see Table 3). The results reflect the fact that the MMDAs have complied with the Act. Those respondents that disagreed with the above statement are not sure that it is seen to be complying fully with the Act's requirements. It was also refreshing to find out that the tender evaluation committee checks all tenders for its oversight role, $(75 \% ; n=79)$ respondents agreed to that as compared to $(25 \% ; n=26)$ respondents undecided or disagreed with the statement saying that at times political influences does not allowed that.

When asked on the statement "all contracts must pass through the procurement processes", all of the respondents agreed to that statement. This finding supports the assertion by [16] that members of procurement committees of MMDAs are aware that all contracts must be awarded through a procurement process to ensure transparency and reduce corruption. All the one hundred and five (105) respondents agreed that MMDAs must prepare a procurement plan that is approved by the entity committee. This further indicates that, they have adequate knowledge concerning the Act, $(86 \%$; $\mathrm{n}=91)$ respondents agreed that the district assembly tender committee needs at least five members to form a quorum as compared to $(14 \% ; n=14)$ undecided or disagreed with the statement. This is a major requirement of Act 663 and is binding on all public sector institutions. Understanding this requirement has implications to the building of capacity of the district assembly to effectively comply with the Act. This is because the decision to purchase or not should be taken by one officer or a few officers as this results in corruption and financial loss to public sector institutions as well as the government [15].

In spite of the respondent's experiences on the job they still believe training programmes in the knowledge upgrade on the Act is essential. It was evident from the respondents as $(79 \% ; n=83)$ responded positively to the statement that there is the need to establish training programmes on the Act to sharpen their skills while (17\%; $n$ $=18$ ) respondents disagreed with the statement and the other $(4 \% ; n=4)$ were neutral on the statement. When asked about emergency goods and services going through the tender process the results were diverse as (54\%; $n$ = 57) respondents believe that it should be for consistency purposes as any good or service procurement is a public expense and must be handled as such, on the other hand $(46 \% ; n=48)$ respondents were of the view that emergency purposes of goods and services by its nature must be treated as such as certain laid down purchase procedure can be followed and still achieve value for money in procurement. When the respondents were asked whether they are familiar with the Public Procurement Act, Act 663 all respondents responded that they have appreciable fair knowledge of the Act.

When asked whether or not the Procurement Committee Members of the sampled MMDAs comply with the Act by examining how the various modalities are utilised in the procurement process. As one of the modalities for ensuring compliance when respondents were asked if contracts for the supply of goods and services were 
advertised to the public, all the respondents answered in the affirmative. The results is in line with section 19 of the Act (Act 663) which stipulates that all contracts for the supply of goods and services to public sector institutions must be advertised to ensure transparency as shown in Table 4.

To further ascertain compliance, when asked of the medium through which the MMDAs advertised contracts for the supply of goods and services (see Table 4). As revealed by the results of the study $(87.62 \% ; n=92)$ respondents admitted that the national newspapers were used as the major medium through which they advertised their tender information about procurement as compared to $(12.38 \%$; $=13)$ indicated Internet websites as the medium for advertisements.

The length of bidding period is one of the key requirements of the Act [15]. The Act stipulates that the period for bidding should not be less than one week and not longer than six weeks. When respondents were asked how long tenders were opened they provided varying responses as shown in Table 4.

The results from Table 4 indicate that $(88 \% ; \mathrm{n}=92)$ respondents which serve as the majority reported that they open tender bidding for two weeks. This was followed by four weeks $(7 \% ; n=8)$ and three weeks $(5 \% ; n=$ 5) respectively. The results show that all the respondents followed the Procurement Act that requires that the tender bids must be opened for a period not exceeding six weeks.

The Procurement Act also requires entity committees to put in place modalities for reviewing complaints from suppliers and contractors regarding procurement entities. Table 4 indicated that nearly $(61.90 \% ; \mathrm{n}=65)$ respondents confirmed that they have put in place measures to review complaints. As compared to $(38.10 \% ; n=40)$ respondents who said they did not have any avenue to review the complaints emanating from contractors and

Table 4. Procedures used by the MMDAs for procurement of Good and Services.

\begin{tabular}{|c|c|c|c|}
\hline Procedure used by the MMDAs & Responses Category & Frequency & Percentage \\
\hline \multirow[t]{3}{*}{ Assembly advertises contracts } & Yes & 105 & 100.00 \\
\hline & No & 0 & 0.00 \\
\hline & Total & 105 & 100.00 \\
\hline \multirow[t]{3}{*}{ Contracts awards published } & Yes & 98 & 93.33 \\
\hline & No & 7 & 6.67 \\
\hline & Total & 105 & 100.00 \\
\hline \multirow[t]{3}{*}{ Media to publish adverts and awards of contracts } & Newspapers & 92 & 87.62 \\
\hline & Internet websites & 13 & 12.38 \\
\hline & Total & 105 & 100.00 \\
\hline \multirow[t]{4}{*}{ Tenders opened for bidding period } & 2 weeks & 92 & 88.00 \\
\hline & 3 weeks & 5 & 5.00 \\
\hline & 4 weeks & 8 & 7.00 \\
\hline & Total & 105 & 100.00 \\
\hline \multirow[t]{3}{*}{ Modalities for reviewing complaints from supplies and contractors } & Yes & 65 & 61.90 \\
\hline & No & 40 & 38.10 \\
\hline & Total & 105 & 100.00 \\
\hline Statement & Category & Frequency & Percentage \\
\hline \multirow{3}{*}{ Rely on only suppliers with good standing in the supplier index } & Yes & 80 & 76.19 \\
\hline & No & 25 & 23.81 \\
\hline & Total & 105 & 100.00 \\
\hline \multirow{3}{*}{ Documentations verification before awards of contracts } & Yes & 105 & 100.00 \\
\hline & No & 0 & 0.00 \\
\hline & Total & 105 & 100.00 \\
\hline
\end{tabular}

Source: Field Data, 2014. 
suppliers. The result means that $(38.10 \% ; \mathrm{n}=40)$ are not complying with the Act that required institutions to put in place modalities for reviewing complaints from their suppliers.

On the issues of the publication of contract awards $(93.33 \% ; n=98)$ respondents confirmed that awards are published as compared to $(6.67 \% ; n=7)$ who disagreed which means that the compliance issues are not dealt with holistically.

When asked about modalities for reviewing complaints from contractors, several responses came from the respondents in a focus group discussion. The respondents noted that the contractors can appeal to the head of entity, ask for debriefing and appeal to the Public Procurement Authority (PPA), their responses are indication that the MMDA's adhere to the compliance provisions of the Act seriously.

On the other hand as contractors and suppliers are protected by the Act, it also put them on their toes if they fail to perform agreed contracts. The responses from focus group discussion revealed that suppliers/contractors are punished when they fail to deliver within the stipulated time. A member of the focus group discussion noted that "either the contract will be terminated or the said contractor/supplier will be blacklisted". In some cases the contractors were asked to pay the liquidated damages. However, on the other hand the district assembly fails to sanction contractors because of delays in payment of the contractor".

The result of the study also revealed that the MMDA's rely on suppliers with good standing in the supplier index where $(76.19 \%, n=80)$ responded "yes" while the other $(23.8 \% ; n=25)$ responded "no", it makes sense where the supplier index give assurance and conformation of what has to be done. Also documentation verification before awards of contracts is a key issue to ensure compliance, as all the respondents who participated in the focus group discussion agreed on the importance of documentations from the supplier/contractor.

\subsection{Challenges of Complying with the Act}

In adhering to the dictates of the Act, public sector institutions are often confronted with some challenges [15] and procurement Act is no exception. In this study respondents were asked to express their opinions on some of the challenges they face in the implementation of the Act.

Table 5 present key challenges the respondents faced in complying with the procurement Act. The majority of the respondents $(90.48 \% ; \mathrm{n}=95)$ disagreed to the fact that they see the Act as being more controlling than facilitating the procurement process. This is against $(9.52 \% ; n=10)$ respondents who disagreed or neutral on that

Table 5. Challenges of implementation of the procurement Act by MMDAs.

\begin{tabular}{|c|c|c|c|}
\hline & Agree & Neutral & Disagree \\
\hline Challenges in the implementation of the Public Procurement Act & Freq. (\%) & Freq. (\%) & Freq. (\%) \\
\hline $\begin{array}{l}\text { The Act is designed to be more controlling than facilitating the procurement } \\
\text { process itself }\end{array}$ & $5(4.76 \%)$ & $5(4.76 \%)$ & $95(90.48)$ \\
\hline $\begin{array}{l}\text { The Act does not allow for introduction of innovative techniques in the } \\
\text { procurement process }\end{array}$ & $91(86.67 \%)$ & $6(5.71 \%)$ & $8(7.62 \%)$ \\
\hline $\begin{array}{l}\text { The Act ensures that the cheapest service is obtained but not the best in terms } \\
\text { of quality }\end{array}$ & $92(87.62 \%)$ & $5(4.76 \%)$ & $8(7.62 \%)$ \\
\hline The procurement process is very bureaucratic & $95(90.48 \%)$ & $5(4.76 \%)$ & $5(4.76 \%)$ \\
\hline There are technical difficulties in applying the Act in all aspects & $50(47.62 \%)$ & $0(0.00 \%)$ & $55(52.38 \%)$ \\
\hline Frequent changes in membership of tender board affect the procurement process & $44(41.90 \%)$ & $30(28.60 \%)$ & $31(29.50 \%)$ \\
\hline $\begin{array}{l}\text { Limited logistics (computers, office space etc.) slows down the work of } \\
\text { tender committee }\end{array}$ & $41(39.00 \%)$ & $30(29.00 \%)$ & $34(32.00 \%)$ \\
\hline $\begin{array}{l}\text { Tender committee members do not have the requisite skills and training } \\
\text { in the procurement process. }\end{array}$ & $90(86.00 \%)$ & $0(0.00 \%)$ & $15(14.00 \%)$ \\
\hline Tender committee members do not receive rewards for their services & $75(71.42 \%)$ & $15(14.29 \%)$ & $15(14.29 \%)$ \\
\hline External pressure to subvert the procurement process & $80(76.19 \%)$ & $20(19.05 \%)$ & $5(4.76 \%)$ \\
\hline Most suppliers and contractors do not look for adverts on procurement & $65(61.90 \%)$ & $25(23.81 \%)$ & $15(14.29 \%)$ \\
\hline The Act has made the procurement of goods and services very risky & $12(11.43 \%)$ & $33(31.43 \%)$ & $60(57.14 \%)$ \\
\hline Most suppliers and contractors cannot obtain the needed documents & $60(57.14 \%)$ & $20(19.05 \%)$ & $25(23.81 \%)$ \\
\hline
\end{tabular}

Source: Field Data, 2014. 
statement. Again, most of the respondents $(86.67 \% ; \mathrm{n}=91)$ agreed that the Act does not allow for the introduction of innovative techniques in the procurement process, compared to $(7.62 \% ; n=8)$ respondents that disagreed while $(5.71 \% ; n=6)$ were neutral in their opinion.

The majority of the respondents $(86.67 \% ; \mathrm{n}=91$ ) felt the Act ensures that the cheapest service is obtained but not the best in terms of quality and value for money compared to $(5.7 \%$; $=6)$ who were not certain, while $(7.62 \% ; n=8)$ disagreed with the statement. Similarly, $(90.48 \% ; n=95)$ respondents felt the procurement process was very bureaucratic, compared to $(9.52 \%, \mathrm{n}=10)$ were uncertain or disagreed on the statement.

A member of the focus group discussion noted this in response to his comment on the extent of the implementation of the public procurement Act, he revealed that "the times have changed and therefore the Act needs to be reviewed to enable free and transparent implementation especially by the political leaders". The District Chief Executive was positive that the public procurement Act has enhanced the procurement process.

[10] stated that each country has its own economic, social, cultural and political environment, and each country's public procurement practitioners face different types of challenges, or the same types of challenges but at different levels from their counterparts in other countries.

Furthermore, reasons for the lack of success in implementing reforms in developing countries are varied but also interlinked. The most difficult obstacle is the lack of political will at the highest levels of Government to significantly overhaul an existing system [7].

Facing the above challenges and others like rapid development in technology (which has brought about new procurement methods), public procurement cannot be perceived as a mere clerical routine but public procurement practitioners should be involved in strategic procurement planning [17].

When asked about what provisions of the Act does the MMDA's find it difficult to apply currently, two members of the focus group revealed the following, one member said "the limitation of the Mayor, Municipal and District Chief Executives powers to award contract beyond a stipulated amount of threshold", Another member said his concern is on the "submission of reports/documents to the PPA-such as the procurement plans award notification". Their concerns were surprising and shocking, what will be the essence of the Act if the MMDA's have so much power in terms of spending though he/she will account for it. This will lead to abuse of power and even spending beyond the budget of the assemblies, with the other member least said about his difficulty; after spending the money who should do the documentation and send it to the PPA on their behave; this is a challenge to the PPA.

The key to the attainment of compliance to the Procurement Act is the understanding of the procurement guidelines. From Table 5, it depicts that, on the issue of technical difficulties in applying the Act, $(47.62 \% ; \mathrm{n}=$ 50 ) respondents stated that there are some technical difficulties in applying the Act as compared to $(52.38 \% ; n=$ 55) who disagreed with the statement. There is the need for PPA to ensure that public institutions understand the Act and its guidelines were to be applied if problems of non-compliance are to be removed.

In order to carry out the compliance of the Act in a most effective manner, there is the need for the tender committee to have access to all the logistics to carry out their duties and responsibilities to add value and save the taxpayers money. On whether limited logistics slows down the work of the tender committee the responses that came out were, $(39 \% ; n=41)$ respondents agreed with the statement as compared to $(32 \% ; n=34)$ respondents disagreeing on the issue while $(29 \% ; n=30)$ were neutral. This was attributed to the non-availability of those items from logistics perspective. The finding calls for the Assemblies to improve its functions and operations to ensure compliance.

Specialised procurement training plays a pivotal role in acquiring new skills and enhancing efficiency. From Table 5, it was observed that $(86 \% ; n=90)$ respondents agreed that some of the tender committee members do not have the requisite skills and training in the procurement process as against $(14 \%$; $n=15)$ respondents who disagreed on the issue. This is a worrying situation because it can have a negative effect on compliance on procurement procedures.

On the external pressure to subvert the procurement process, it was observed from Table 5 that $(76.19 \% ; n=$ 80) respondents agreed to the fact that there are undue pressure and interference from superiors and organisations for their selfish interest as compared to $(19.05 \%$; $n=20)$ who were neutral on the statement but $(4.76 \%$; $n$ = 5) respondents disagreed and believe that there was no external forces interfering with the procurement procedures. The public procurement committee must be allowed to perform its procurement functions independently without undue pressure or interference from other sections of the organization if benefits are to be seen. The finding was observed with great concern as it can lead to non-compliance of the procurement guidelines. 
The preparation of the bidding document is very important and therefore procurement committee members must ensure that this is properly done. The respondents were asked if suppliers and contractors cannot obtain the needed documents to go through the procurement tendering process. It was observed that $(57.14 \% ; n=60)$ agreed that suppliers and contractors most of the time cannot obtain the needed documents while $(19.05 \% ; \mathrm{n}=$ 20) respondents were indifferent on the issue. The other $(23.81 \%$; $n=25)$ respondents were of the opinion that they disagreed with the statement which imply suppliers and contractors are able to present the needed documents as part of the tendering process. This result demonstrates a shortfall in the effectiveness of the procurement committee as it point to the fact that extra efforts need to be put in place by the Assemblies to compel the suppliers and contractors to provide all the relevant documents if they will be shortlisted in the tendering process.

\subsection{Conclusion and Recommendation}

Public procurement is inherently a politically sensitive activity, not just because it involves significant amounts of public money even within the context of a national economy. By its magnitude, public procurement demands high quality public governance in terms of transparency and accountability as well as effective management that can deliver optimum risk management and value for money. A highly regulated procurement environment designed could be appropriate to minimise discretion in circumstances where there are considerations of high risk from undue influence. Moreover, a highly prescriptive approach may also seem appropriate in jurisdictions where officials have minimal procurement skills, in striving to ensure transparency or prevent or overcome corruption.

The study engages with the MMDAs on their procurement activities and the implementation challenges with the Public Procurement Act 2003 (Act 663) in the Ashanti Region. The paper provides evidence from the study which suggests these conclusions of the study:

The level of knowledge regarding the Public Procurement Act is very high as all contracts are awarded by a tender committee and all contracts also pass through the procurement processes. Notwithstanding this, there is a need for capacity building to adequately equip employees with the necessary skills needed to ensure compliance.

The adherence to the modalities for compliance with the Public Procurement Act is encouraging as the MMDAs have done enough to raise the importance of ensuring compliance to the procurement procedures.

Challenges of the implementation of the Public Procurement Act were diverse with mixed reactions. It was important that, the Act facilities the process of procurement where it is perceived that it controls the process. There were diverse opinions on the technical difficulties of the application of the Act. It was strongly acknowledged that, tender committee members do not have the requisite skills and training in the procurement process; moreover there is a worrying situation of the public knowledge that there are immense external pressures to subvert the procurement process.

Based on the findings of the study, the following recommendations were made in order to ensure that MMDAs will be effective if its operations and these public institutions adhere to all procurement compliances of the Public Procurement Act 2003 (Act 663) religiously:

Even though the procurement committee members of the assembly understand the provisions of the Act, they are not able to fully comply with the Act due to the lack of expertise to fully comply with the law. It is therefore recommended that the Public Procurement Authority should organise regular training programmes to expose stakeholders involved in the procurement process to the provisions and modalities for implementing the Act. This will help to develop the competencies and capacities of the procurement committee members and staff of the assembly as well as their suppliers in the implementation of the Act.

The Public Procurement Authority has to step up its monitoring and compliance assurance role within the assemblies. The period of monitoring should be regular, at least quarterly to ensure that lapses do not occur.

The most important way to improve upon compliance with the Public Procurement Act, 2003 is to insulate routine procurement decisions from political interference or at least, reduce to a minimum. This requires that political leaders must muster the necessary political will to implement the Act in full.

However, it would be interesting and insightful to conduct a comparative study of all the twenty-seven (27) MMDAs in the Ashanti Region on the application and compliance of the Public Procurement Act 2003 (Act 663). It is therefore suggested that future studies must use all the MMDAs as census for the study to authenticate the validity of the results. 


\section{References}

[1] Mlinga, R. (2009) Promoting Integrity in Public Procurement. Tanzania Procurement Journal, II, 13-39.

[2] Adjei, A.B. (2005) Public Procurement Authority: What Are We Learning from Different Approaches to Monitoring Capacity and Development? An Assessment Tool for Public Procurement System and Its Application to Monitoring Capacity and Performance of the Procurement System in Ghana, Accra.

[3] World Bank (2003) Economic Report on Ghana. Ghana Country Department, The World Bank, Washington, DC.

[4] Wittig, W.A. (1999) Building Value through Procurement: A Focus on Africa. Paper Presented to the 9th International Anti-Corrupting Conference, Durban.

[5] Transparency International (2006) Handbook for Curbing Corruption in Public Procurement. Berlin.

[6] OECD (2007) Integrity in Public Procurement: Good Practice from A to Z. Organisation for Economic Cooperation and Development, Paris.

[7] Hunja, R.R. (2003) Obstacles to Public Procurement Reform in Developing Countries. Kluwer International, The Netherlands.

[8] McDonald, C. (2008) Christian Aid. Buying Aid Power, Governance and Public Procurement, Accra.

[9] Falvey, R. (2012) Competition Policy and Public Procurement in Developing Countries. http://www.nottingham.ac.uk/credit/documents/papers/08-07.pdf

[10] Thai, K.V. (2001) Public Procurement Reexamined. Journal of Public Procurement, 1, 9-50.

[11] Arrowsmith, S. (2005) The Law of Public and Utilities Procurement. 2nd Edition, Sweet and Maxwell, London.

[12] Adjei, A.B. (2006) Message from the Chief Executive. Ghana Public Procurement Board.

[13] Anvuur, A., Kumaraswamy, M.M. and Male, S. (2006) CIW 107 Construction in Developing Economies Symposium in Taking Forward Public Procurement in Ghana, Santiago.

[14] Rofstam, A.G. (2008) Procurement Policy and Contracting Efficiency. International Economic Review, 34, 873-901.

[15] Aglomessa, F.J. (2010) Procurement Reform in Sierra Leone: A Public Choice Model of Analysis. Proceedings of the International Public Procurement Conference, Fort Lauderdale, 21-23 October 2010.

[16] Greuning, H. (2009) International Financial Reporting Standards. A Practical Guide. 5th Edition, World Bank Publications, Washington DC. http://dx.doi.org/10.1596/978-0-8213-7727-7

[17] Thai, K.V. (2009) International Handbook of Public Procurement. Auerbach Publications, Boca Raton. 